\title{
Oxidation of Dibenzyl Sulfide via an Oxygen Transfer from Palladium Nitrate
}

\author{
Young-ae Whang Park, Yongho Na, and Du-Jong Baek* \\ Department of Chemistrv, College of Natural Sciences, Sangmwung Chiversitu, Seoul 110-743, Korea. "E-mail djbaekiâsmuac.k" \\ Received July 31, 2006
}

\begin{abstract}
Dibenzyl sulfide was oxidized at the $\alpha$-carbon to yield benzaldelyde in the presence of $\mathrm{Pd}\left(\mathrm{NO}_{3}\right)_{2}$. Oxygen itself could not oxidize the sulfide directly. instead the nitrato ligand of the palladiun complex transferred oxygen to dibenzyl sulfide to form benzaldehyde. The X-ray crystal structure of the intermediate conplex. cis$\left[\mathrm{Pd}\left(\mathrm{NO}_{3}\right)_{2}\left\{\mathrm{~S}\left(\mathrm{CH}_{2} \mathrm{C}_{6} \mathrm{H}_{3}\right)_{2}\right\}_{2}\right]$. revealed that the nitrato ligand was unidentate. Para-substituted dibenzyl sulfides I. $\left(\mathrm{YC}_{6} \mathrm{H}_{4} \mathrm{CH}_{2}\right)_{2} \mathrm{~S}$ wherein $\mathrm{Y}=\mathrm{OCH}_{3} . \mathrm{CH}_{3} . \mathrm{Cl}_{3} \mathrm{CN}$. or $\mathrm{NO}_{2}$. were synthesized and reacted with palladium nitrate, and those with electron-donating substituents $\left(\mathrm{Y}=\mathrm{OCH}_{s}\right.$ and $\mathrm{CH}_{3}$ ) were good substrates for the oxidation reaction with palladium nitrate. Thus, the reaction mechanism of the oxygen transfer was proposed to include nucleophilic benzy lic carbon
\end{abstract}

Key Words: Dibenẓ̧l sulfide. Palladium nitrate. Benzaldehỵde. Oxidation

\section{Introduction}

Oxidation of organic sulfides by chenical reagents generally yields either sulfoxides or sulfones. ${ }^{1}$ On the contrary. radical-induced autoxidation of organic sulfides in the liquid phase proceeds to yield carboxylic acids by the introduction of oxygen into the sulfides at the $\alpha$-carbon atom. ${ }^{2}$ Various organic sulfides are readily autoxidized to acidic products in the base-catalyzed conditions such as potassium terbutoxide-hexamethylphosphoramide system. ${ }^{3-5}$ Other nonradical routes for oxidation include the splitting of oxygen molecule on a ligand of a transition metal complex to form a complex with the oxidized ligand. and the oxygen of this ligand would then transfer to organic substrate. This chemistry was first investigated for the nitro/nitrosyl redox couple as shown in Scheme 1(a). ${ }^{6-8}$ Transition metal-nitrato complexes are also known to have remarkable reactivity towards organic substrates for several decades. ${ }^{9,11}$ Postel and her coworkers demonstrated that iron-nitrato/iron-nitrosy] could also constitute a redox couple (Scheme $1(\mathrm{~b}))^{11-13}$ In this redox system, the N-bonded nitrosyl ligand was oxidized by $\mathrm{O}$ : into a bidentate $\mathrm{O}$-bonded nitrato group which, in turn. transferred oxygen to alkenes or phosphines and was thus reduced to the initial $\mathrm{N}$-bonded nitrosyl group. The

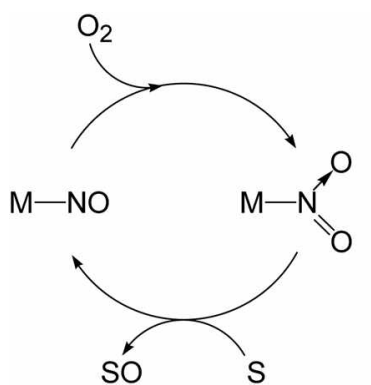

(a)

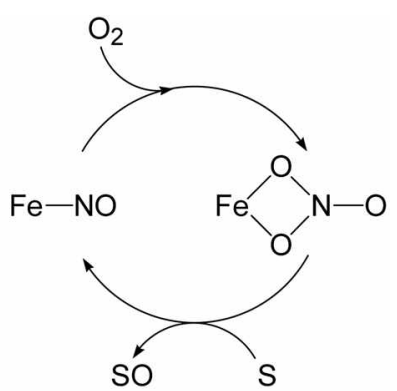

(b)
Scheme 1. (a) Nitrohintrosyl and (b) Nitrato/nitrosyl redos couple. $M$ and $S$ denote transition metal and organic substrate, respectively. nitrate ion has been known to coordinate the metal through oxygen by three different modes as unidentate, bidentate or bridging bidentate. ${ }^{1,15}$ Maximum reactivity is observed in the bidentate case as above, thus most of the works on the nitrato/nitrosy] redox couple in the literature deal with bidentate nitrate complexes.

In the case of palladiun complex. oxygen transfer reaction wa palladium-nitrato/palladium-nitrosyl couple has never been reported before. though treatment of $\left[\mathrm{Pd}\left(\mathrm{NO}_{3}\right)_{2} \mathrm{~L}_{2}\right]$ $\left(\mathrm{L}=\mathrm{PPl}_{3}\right.$ or $\mathrm{PEt}_{3}$ ) with $\mathrm{NO}$ or $\mathrm{CO}$ was reported to cause deosygenation to give nitro species $\left[\mathrm{Pd}\left(\mathrm{NO}_{2}\right)_{2} \mathrm{~L}_{2}\right]^{\text {te }}$ Therefore, we report here the first case of the potential unidentate palladium-nitrato/palladium-nitrosyl redox couple for the oxidation of dibenzyl sulfide to benzaldehyde. along with the synthesis and reactions of various para-substituted dibenzyl sulfides for the elucidation of the reaction mechanism of oxygen transfer from palladium nitrate.

\section{Results and Discussion}

In our previous work on the dehydrogenation reaction of cyclohexanone with $\mathrm{Pd}\left(\mathrm{NO}_{3}\right)_{2}$-dibenzyl sulfide catalytic system, benzaldehyde, the oxidation product of dibenzyl sulfide. was also observed in addition to the dehydrogenated product. ${ }^{17}$ In order to verify the oxidant of this reaction dibenzyl sulfide was reacted under $\mathrm{O}_{2}$. but it did not give benzaldehyde. Then. when dibenzyl sulfide was reacted with $\mathrm{Pd}\left(\mathrm{NO}_{3}\right)_{2}$ under $\mathrm{O}_{2}$, benzaldehyde was observed, and further, the same reaction without $\mathrm{O}_{2}$ (under $\mathrm{N}_{2}$ ) yielded benzaldehyde as well. Therefore, it was proved that the main oxidant in this reaction was $\mathrm{Pd}\left(\mathrm{NO}_{3}\right)_{2}$. It is remarkable that benzaldelyyde was not oxidized further to benzoic acid even after a long period of time in this reaction condition

Spectroscopic analysis. The oxidation reaction was monitored with NMR spectroscopy. The mixture of dibenzyl sulfide and $\mathrm{Pd}\left(\mathrm{NO}_{3}\right)_{2}$ in benzene- $c_{0}$ under $\mathrm{O}_{2}$ in a sealed NMR tube was gradually heated from ambient temperature to $80{ }^{\circ} \mathrm{C}$ in NMR spectrometer. At the beginuing. the 
resonance peak of the benzylic proton of dibenzyl sulfide appeared at $3.3 \mathrm{ppm}$. and this peak was shifted down to 3.6 $\mathrm{ppm}$ as the reaction proceeded. meaning that the sulfide was coordinated to palladium metal. At $50^{\circ} \mathrm{C}$. a new peak at 9.6 $\mathrm{ppm}$ started to grow. which indicated that benzaldehyde was beginning to form. At $80^{\circ} \mathrm{C}$. the growth of the peak discontinued after an hour. The reaction was also monitored with IR spectroscopy. When the reaction of dibenzyl sulfide with $\operatorname{Pd}\left(\mathrm{NO}_{3}\right)_{2}$ in methylene chloride under $\mathrm{N}_{2}$ was carried out at $10^{\circ} \mathrm{C}$. orange-red crystalline product probably the intermediate complex. was isolated. The IR absorption bands of the complex observed at 1480.1260 and $985 \mathrm{~cm}^{-1}$ could be assigned to a unidentate nitrato group. However, as the temperature of the above reaction was raised and brought to reflux, oily product was obtained and a new absorption band appeared at $1688 \mathrm{~cm}^{-1}$ in its IR spectrum, indicating the characteristic Pd-NO bond formed by the oxygen transfer from the nitrate. Since Pd-NO complex was isolated only as oil. we could not carry out the reverse reaction to form palladium-nitrato complex from palladium-nitrosyl complex. From the above NMR and IR results. we concluded that dibenzyl sulfide was oxidized to benzaldehyde by transferring oxygen atom from the palladium-nitrato complex and. in turn. the nitrato-ligand itself was reduced to form palladium-nitrosyl complex.

$\mathrm{X}$-ray crystal structure of the intermediate complex. It was proved further that the intermediate complex. the orange-red crystalline product obtained at $10^{\circ} \mathrm{C}$. was cis$\left[\mathrm{Pd}\left(\mathrm{NO}_{3}\right)_{2}\left\{\mathrm{~S}\left(\mathrm{CH}_{2} \mathrm{Ph}\right)_{2}\right\}_{2}\right]$ by $\mathrm{X}$-ray crystallography as illustrated in Figure 1. Selected bond lengths and bond angles with estimated standard deviations are given in Table 1 . The complex is square planar. and the nitrato ligand is bonded through an oxygen atom to the metal as unidentate. which is supported further by the fact that the bond length between nitrogen and the coordinated oxygen $(1.32 \mathrm{~A})$ is longer than those between nitrogen and two uncoordinated oxygen atoms $(1.20 \mathrm{~A}$ ) by $0.12 \mathrm{~A}$ in the nitrato ligand. It is worth to note that this unidentate nitrato ligand is unique since most of the metal-nitrato complexes undergoing oxygen transfer reaction comprise bidentate nitrato ligands.

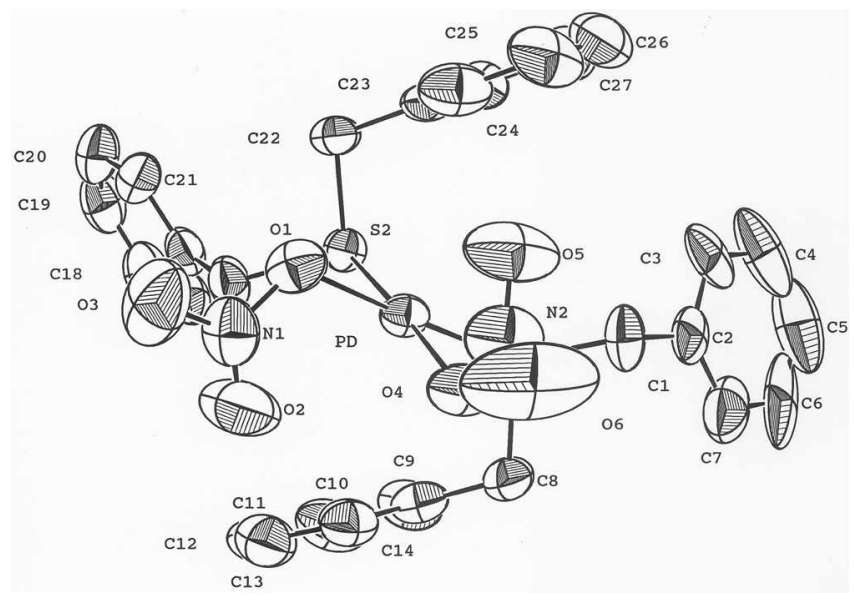

Figure 1. Molecular structure of $c i s-\left[\mathrm{Pd}\left(\mathrm{NO}_{3}\right)_{2}\left\{\mathrm{~S}\left(\mathrm{CH}_{2} \mathrm{Ph}\right)_{2}\right\}_{2}\right]$.
Table 1. Selected bond lengths $(\AA)$ and bond angles (deg) with estimated standard deviations for cis- $\left[\mathrm{Pd}\left(\mathrm{NO}_{3}\right)_{2}\left\{\mathrm{~S}\left(\mathrm{CH}_{2} \mathrm{Ph}\right)_{2}\right\}_{2}\right]$

\begin{tabular}{cccc}
\hline $\mathrm{Pd}-\mathrm{S}_{1}$ & $2.258(2)$ & $\mathrm{N}_{1}-\mathrm{O}_{1}$ & $133(1)$ \\
$\mathrm{Pd}-\mathrm{S}_{2}$ & $2.277(2)$ & $\mathrm{N}_{1}-\mathrm{O}_{2}$ & $116(1)$ \\
$\mathrm{Pd}-\mathrm{O}_{1}$ & $2.063(5)$ & $\mathrm{N}_{1}-\mathrm{O}_{3}$ & $122(1)$ \\
$\mathrm{Pd}-\mathrm{O}_{4}$ & $2.053(7)$ & $\mathrm{N}_{2}-\mathrm{O}_{4}$ & $130(1)$ \\
& & $\mathrm{N}_{2}-\mathrm{O}_{4}$ & $123(1)$ \\
& & $\mathrm{N}_{2}-\mathrm{O}_{6}$ & $119(1)$ \\
\hline $\mathrm{S}_{1}-\mathrm{Pd}-\mathrm{S}_{2}$ & $86.7(8)$ & $\mathrm{O}_{1}-\mathrm{Pd}-\mathrm{O}_{4}$ & $91.6(2)$ \\
$\mathrm{S}_{1}-\mathrm{Pd}-\mathrm{O}_{4}$ & $91.3(2)$ & $\mathrm{O}_{1}-\mathrm{Pd}-\mathrm{S}_{1}$ & $99.5(5)$ \\
$\mathrm{S}_{1}-\mathrm{Pd}-\mathrm{O}_{1}$ & $176.8(2)$ & $\mathrm{S}_{2}-\mathrm{Pd}-\mathrm{O}_{4}$ & $175.8(2)$ \\
\hline
\end{tabular}

Synthesis of substituted dibenzyl sulfides and oxidation reactions of the sulfides with palladium nitrate. The parasubstituted dibenzyl sulfides $\mathrm{I}$. $\left(\mathrm{YC}_{6} \mathrm{H}_{4} \mathrm{CH}_{2}\right)_{2} \mathrm{~S}$ wherein $\mathrm{Y}=$ $\mathrm{OCH}_{3} . \mathrm{CH}_{3} . \mathrm{Cl} . \mathrm{CN}$. or $\mathrm{NO}_{2}$. were synthesized from their corresponding benzyl bronides in the presence of sodium sulfide in $40-85 \%$ vields. The substituents were chosen as either electron-donating or electron-withdrawing in order to examine whether the mechanism of the oxygen transfer from palladium nitrate was nucleophilic or electrophilic. Each sulfide was reacted with palladium nitrate in toluene by heating to reflux under oxygen. and the generated benzaldehyde was analyzed by GC at various time intervals. The semilogarithmic plot of the concentration of benzaldelyde against time gave a straight line with a slope of first-order rate constant $k$ and the values for the substituted dibenzyl sulfides are listed in Table 2 along with the vields of the generated benzaldehydes. The rate constant for dibenzyl sulfide Ic $(Y=H)$ was $0.072 \mathrm{~min}^{-1}$. and those of Ie and If $(Y$ $=\mathrm{CN}$ and $\mathrm{NO}_{2}$ ) were 0.0027 and $0.0030 \mathrm{~min}^{-1}$. respectively. This results show that the reaction rates of the sulfides with strong electron-withdrawing substituents are 24- to 27-fold slower than that of dibenzyl sulfide Ic. Contrary to this. the rate constants for sulfides Ia and Ib with electron-donating substituents $\left(\mathrm{Y}=\mathrm{OCH}_{3}\right.$ and $\mathrm{CH}_{3}$ ) were 0.087 and 0.054 $\mathrm{min}^{-1}$. respectively, similar to that of dibenzyl sulfide Ic Even though the electron-donating substituents in these sulfides Ia and Ih did not increase the reactivity. however. the maximum amounts of benzaldehy'des were $20 \%$ and $15 \%$. respectively, which were high enough compared to those of the other reactions $(6-9.5 \%)$. From these results. it is obvious that the benzylic carbon of dibenzyl sulfide in the $\mathrm{Pd}\left(\mathrm{NO}_{2}\right)_{2}$-sulfide complex should be nucleophilic. so we propose the plausible mechanism of formation of benzaldehy'de from dibenzyl sulfide in Scheme 2. Initially, oxide ion of the nitrato ligand in structure II absorbs a proton at the benzylic carbon producing carbanion. which is quite stabilized by forming ylide with the adjacent sulfonium ion as seen in structure III. This benzylic carbanion is nucleophilic. thus attacks the nitronium ion to form 5-menbered ring in IV. Then, after proton exchange. 6-membered ring is formed as in structure VI by the attack of $\mathrm{N}$-oxide in $\mathbf{V}$ to the benzylic carbon and simultaneous $\mathrm{C}-\mathrm{N}$ bond cleavage. Finally. basecatalyzed electron transfer and the sequential N-O and C-S bond cleavages result in the generation of benzaldehyde and 
Table 2. Oxidation reactions of the para-substituted dibenzyl sulfides with palladium nitrate

\begin{tabular}{lcc}
\hline$\left(\mathrm{YC}_{6} \mathrm{H}_{4} \mathrm{CH}_{2}\right)_{2} \mathrm{~S}$ & Rate constant $\left(\mathrm{mim}^{-1}\right)$ & Yield of $\mathrm{YC}_{6} \mathrm{H}_{4} \mathrm{CHO}(\%)$ \\
\hline Ia, $\mathrm{Y}=p_{p}-\mathrm{OCH}_{3}$ & 0.087 & 20 \\
Ib, $\mathrm{Y}={ }_{p}-\mathrm{CH}_{3}$ & 0.054 & 15 \\
Ic, $\mathrm{Y}=\mathrm{H}$ & 0.072 & 6 \\
Id, $\mathrm{Y}=p^{-\mathrm{Cl}}$ & 0.066 & 7.5 \\
Ie, $\mathrm{Y}=p-\mathrm{CN}$ & 0.0027 & 6 \\
If, $\mathrm{Y}=p-\mathrm{NO}_{2}$ & 0.0030 & 9.5 \\
\hline
\end{tabular}<smiles>CC(C)(c1ccccc1)[Pb](C)(C)O[N+](=O)[O-]</smiles>

II<smiles>C[S+]1(Cc2ccccc2)OC2(c3ccccc3)CCCC1C[N+]([O-])(O)C2</smiles>
V<smiles>CNC(=O)C(C)(N)N</smiles>

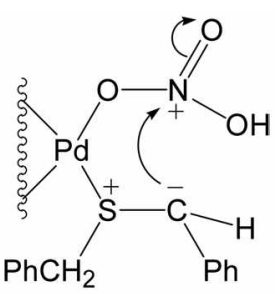

III

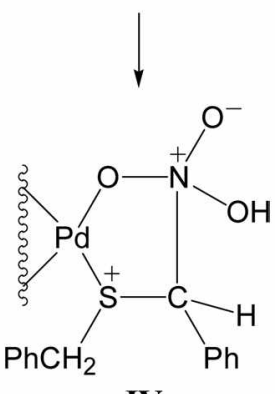

IV

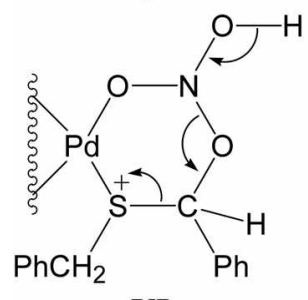

VI<smiles>O=CC(=O)c1ccccc1</smiles>

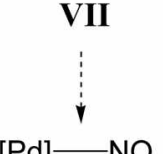

Scheme 2. Plausible mechanism of the formation of benzaldehyde from dibenzyl sulfide.

palladium-nitro complex VII. This nitro complex is further reduced to palladium-nitrosyl complex eventually. and similar mechanisms of the oxygen transfer reactions between metalnitrato/nitrosyl or metal-nitro/nitrosyl were described in the literature. ${ }^{18,19}$

In conclusion. dibenzyl sulfide was oxidized at the $\alpha$ carbon to produce benzaldehyde in the presence of $\mathrm{Pd}\left(\mathrm{NO}_{3}\right)_{2}$. Oxygen itself could not oxidize the sulfide directly. instead the nitrato ligand of the palladium complex transferred oxygen to dibenzyll sulfide to form benzaldehy'de. The X-ray' crystal structure of the intermediate complex. cis- $\left[\mathrm{Pd}\left(\mathrm{NO}_{3}\right)_{2}\right.$ -
$\left.\left\{\mathrm{S}\left(\mathrm{CH}_{2} \mathrm{C}_{6} \mathrm{H}_{5}\right)_{2}\right\}_{2}\right]$, revealed that the nitrato ligand was unidentate. Various para-substituted dibenzyl sulfides were synthesized and reacted with palladium nitrate in order to elucidate the reaction mechanism of the oxygen transfer from palladium nitrate. Those with electron-donating substituents $\left(\mathrm{OCH}_{3}\right.$ and $\left.\mathrm{CH}_{3}\right)$ were good substrates for the oxidation reactions. thus the reaction mechanism of the oxygen transfer was proposed to include nucleophilic benzylic carbon.

\section{Experimental Section}

General. GC data were collected on a Hewlett Packard 5890 Series II gas chromatograph that employed a FID detector and a HP-5 capillary column ( $25 \mathrm{~m} \times 0.32 \mathrm{~mm})$, and GC-MS spectra were obtained on a Varian GCMS-3400 spectrometer with a DB-5 column. ${ }^{1} \mathrm{H}$ NMR spectra were determined at $250 \mathrm{MHz}$ on a Bruker Avance 250 spectrometer. and chemical shifts were reported in $\delta$ scale in parts per million from tetramethylsilane as an internal standard. Peak multiplicities were designated as follows: s. singlet: $d$. doublet: and $\mathrm{m}$. multiplet. IR absorption spectra were taken on a Perkin-Elmer 16F-PC FT-IR spectrometer. Elemental analysis was performed in the Advanced Analysis Center. Korea Institute of Science and Technology: Melting points were determined on a Barnstead/Electrothennal IA9200 apparatus and were uncorrected. Thin-lay'er chromatography (TLC) was performed with E. Merck silica gel $60 \mathrm{~F}-254$ precoated glass plates $(0.25 \mathrm{~mm})$, and flash column chromatography was performed using E. Merck silica gel 60 $(40-63 \mu \mathrm{m}){ }^{3.1}$ All reagents and solvents were reagent grade, and solvents were purified by published procedures and stored under argon.

Reaction of dibenzyl sulfide under oxygen. A solution of $95 \mathrm{mg}$ of dibenzyl sulfide $(0.434 \mathrm{mmol})$ in $5 \mathrm{~mL}$ of methylene chloride in Schlenk flask was flushed with oxygen gas. and the reaction mixture was heated to reflux for $1.5 \mathrm{hr}$. After cooling. $1 \mathrm{~mL}$ of the reaction mixture was added to $2 \mathrm{~mL}$ of $\mathrm{n}$-hexane, stirred for $10 \mathrm{~min}$, and filtered through Celite. then the filtrate was analyzed by GC-MS: me $214\left(\mathrm{M}^{+}\right)$for dibenzyl sulfide.

Reaction of dibenzyl sulfide with palladium nitrate. A solution of $95 \mathrm{mg}$ of dibenzyl sulfide $(0.434 \mathrm{mmol})$ and 50 $\mathrm{m} g$ of palladium nitrate $(0.217 \mathrm{mmol})$ in $5 \mathrm{~mL}$ of methy lene chloride in Schlenk flask was flushed with oxygen or nitrogen gas. and the reaction mixture was heated to reflux for $1.5 \mathrm{hr}$. After cooling. $1 \mathrm{~mL}$ of the reaction mixture was added to $2 \mathrm{~mL}$ of $\mathrm{n}$-hexane, stirred for $10 \mathrm{~min}$, and filtered through Celite. then the filtrate was analyzed by GC-MS: me $106\left(\mathrm{M}^{+}\right)$for benzaldelyyde.

NMR analysis of the reaction of dibenzyl sulfide with palladium nitrate. The ${ }^{1} \mathrm{H}$ NMR spectrum of a solution of $95 \mathrm{mg}$ of dibenzyl sulfide $(0.434 \mathrm{mmol}) \mathrm{in} 1.5 \mathrm{~mL}$ of berzene- $d_{6}$ in pressure/vacuum NMR tube was taken at room temperature: $\delta 3.3$ (s. $4 \mathrm{H}$ ). $7.2-7.4(\mathrm{~m} . \mathrm{l}(0 \mathrm{H})$. Palladium nitrate $(50 \mathrm{mg} .0 .217 \mathrm{mmol}$ ) was added to the NMR tube and the mixture was flushed with oxygen gas, then the valve was 
closed well. and spectrum was taken: $\delta 3.6(\mathrm{~s}), 7.2-7.4(\mathrm{nt})$. The temperature was elevated to $50^{\circ} \mathrm{C}$. and after $10 \mathrm{~min}$ at this temperature spectrum was taken: $\delta 3.6(\mathrm{~s}), 7.2-7.4(\mathrm{~m})$. 9.6 (s). Then. spectra were taken at higher temperatures as follows: after $10 \mathrm{~min}$ at $60^{\circ} \mathrm{C}$. after $10 \mathrm{~min}$ at $70^{\circ} \mathrm{C}$. and every 15 min for 2 lor at $80^{\circ} \mathrm{C}$.

IR analysis of the intermediate complexes from the reaction of dibenzyl sulfide with palladium nitrate. A solution of $190 \mathrm{mg}$ of dibenzyl sulfide $(0.868 \mathrm{mmol})$ and $100 \mathrm{mg}$ of palladium nitrate $(0.434 \mathrm{mmol})$ in $10 \mathrm{~mL}$ of methylene chloride in Schlenk flask was flushed with nitrogen gas maintaining the temperature under $10^{\circ} \mathrm{C}$. and reacted at that temperature for $30 \mathrm{~min}$. Half of the reaction mixture was filtered through Celite. and the orange-red crystals obtained after the evaporation of the solvent were analyzed by IR spectrometer as $\mathrm{KBr}$ pellet: 1480.1260 .985 $\mathrm{cm}^{-i}$. The remaining half of the reaction mixture was heated to reflux for an additional $30 \mathrm{~min}$ and filtered through Celite. and the red-brown oil obtained after the evaporation of the solvent was analyzed by IR spectrometer as a neat spectrum: $1688 \mathrm{~cm}^{-1}$.

Determination of the $X$-ray crystal structure and characterization of the intermediate palladium-nitrato complex. The orange-red crystals obtained under $10^{\circ} \mathrm{C}$ as mentioned above were recrystallized with a cold $1: 1$ mixture of methylene chloride and n-hexane to form single crystals suitable for X-ray crystallography analysis: ${ }^{1} \mathrm{H}$ NMR $\left(\mathrm{CDCl}_{3}\right) \delta 3.45(\mathrm{~s}, 4 \mathrm{H}) .3 .61(\mathrm{~s} .4 \mathrm{H}), 7.25-7.45$ (n. 20H): IR (KBr) 1559. 1494.1272.980 $\mathrm{cm}^{-1}$ : Anal. Calcd for $\mathrm{C}_{28} \mathrm{H}_{28} \mathrm{~N}_{2} \mathrm{O}_{6} \mathrm{PdS}:$ C. $51.03:$ H. 4.28: N. 4.25; S. 9.73. Found: C. 51.30: H. 4.29: N. 4.19: S. 9.85. Diffraction data were collected on a Rigaku D/Max-IC X-ray diffractometer at the Center for Scientific Instruments. Kyungpook National University. Crystal data and measurement conditions are shown in Table 3 .

Synthesis of substituted dibenzyl sulfides. To a stirred solution of para-substituted benzyl bromide $(20 \mathrm{mmol})$ in 30 $\mathrm{mL}$ of $95 \%$ ethanol. was added a solution of $3.36 \mathrm{~g} \mathrm{(14}$ mmol) of sodium sulfide nonahydrate in $20 \mathrm{~mL}$ of water dropwise. The solution was stirred at room temperature for 40-90 min. then the ethanol was removed by simple distillation. The hot aqueous solution was poured to chipped ice. and after the ice was melted. the solid was filtered washed with cold water and dried. The crude product was purified by flash chromatography on silica gel using $\mathrm{CH}_{2} \mathrm{Cl} /$ n-hexane $(1: 3)$ to give the properly para-substituted dibenzyll sulfide as follows:

Di(p-methoxybenzyl) sulfide (Ia): white solid. $1.29 \mathrm{~g}$ (47\%): mp 52-54 ${ }^{\circ} \mathrm{C}:{ }^{1} \mathrm{H} \mathrm{NMR}\left(\mathrm{CDCl}_{3}\right) \delta 3.56$ (s. $\left.4 \mathrm{H}\right) .3 .81$ $(\mathrm{s}, 6 \mathrm{H}), 6.85$ (d, $4 \mathrm{H} . J=8.7 \mathrm{~Hz}) .7 .20$ (d. $4 \mathrm{H} . J=8.6 \mathrm{~Hz}$ ): Mass mie $274\left(\mathrm{M}^{-}\right), 153.121$.

Di(p-methylbenzyl) sulfide (Ib): white solid, $2.02 \mathrm{~g}(84 \%)$; $\operatorname{mp} 76.5-78.0^{\circ} \mathrm{C}:{ }^{1} \mathrm{H}$ NMR $\left(\mathrm{CDCl}_{3}\right) \delta 2.34(\mathrm{~s}, 6 \mathrm{H}) .3 .60$ (s. $4 \mathrm{H}) .7 .15(\mathrm{~m} .8 \mathrm{H})$ : Mass $m e .242\left(\mathrm{M}^{+}\right) .137,105$.

Di(p-chlorobenzyl) sulfide (Id): white solid. $2.11 \mathrm{~g}(74 \%)$ : mp 41-43 ${ }^{\circ} \mathrm{C}:{ }^{1} \mathrm{H} \mathrm{NMR}\left(\mathrm{CDCl}_{3}\right) \delta 3.56$ (s. $\left.4 \mathrm{H}\right), 7.16$ (n.
Table 3. Crystal data and measurement conditions of cis$\left[\mathrm{Pd}\left(\mathrm{NO}_{3} \mathrm{~h}_{2}\left\{\mathrm{~S}\left(\mathrm{CH}_{2} \mathrm{Ph}\right)_{2}\right\}_{2}\right]\right.$

\begin{tabular}{|c|c|}
\hline Empirical formula & $\mathrm{C}_{28} \mathrm{H}_{28} \mathrm{~N}_{2} \mathrm{O}_{6} \mathrm{Pd} \mathrm{PS}_{2}$ \\
\hline Fonmula weight & 594.94 \\
\hline Crystal system & monoclinic \\
\hline Space group & $\mathrm{P} 2{ }_{1} / \mathrm{ln}(\# 14)$ \\
\hline 2 & 4 \\
\hline \multicolumn{2}{|l|}{ Cell parameter } \\
\hline $\mathrm{a}(A)$ & $9.486(3)$ \\
\hline$b(A)$ & $32.414(8)$ \\
\hline$c(A)$ & $10.067(3)$ \\
\hline$\beta($ deg $)$ & $111.44(2)$ \\
\hline Volume $\left(\AA^{3}\right)$ & $2881(1)$ \\
\hline Density (calculated, $g / \mathrm{cm}^{3}$ ) & 1.519 \\
\hline Absoption coefficient $\left(\mathrm{cm}^{-1}\right)$ & 8.2 \\
\hline Transinission factor & $90.4212-99.8678$ \\
\hline Scan type & $\omega-2 \theta$ \\
\hline Scan width $(\alpha)(\mathrm{deg})$ & $1.03+1.09 \tan (\theta)$ \\
\hline $2 \theta_{\max }(\mathrm{deg})$ & 52.64 \\
\hline No. of reflections measlured & 6327 \\
\hline No. of reflections observed $(\mathrm{I}>3 \sigma(\mathrm{I}))$ & 3790 \\
\hline$F(000)$ & 1216 \\
\hline No. of variables & 352 \\
\hline \multicolumn{2}{|l|}{ Discrepancy indices } \\
\hline $\mathrm{R}$ & 0.0588 \\
\hline $\mathrm{R}_{w}$ & 0.0863 \\
\hline Goodness of fit indicator & 2.54 \\
\hline Maximum shift in final cycle & less than 0.01 \\
\hline
\end{tabular}

8H); Mass me $282\left(\mathrm{M}^{+}\right) .157,125$.

Di(p-cyanobenzyl) sulfide (Ie): white solid. $1.31 \mathrm{~g}(67 \%)$ : mp 114.5-115.5 ${ }^{\circ} \mathrm{C}:{ }^{1} \mathrm{H}$ NMR ( $\left.\mathrm{CDCl}_{3}\right) \delta 3.61$ (s. $\left.4 \mathrm{H}\right) .7 .37$ (d. $4 \mathrm{H}, J=7.1 \mathrm{~Hz}$ ). $7.62(\mathrm{~d}, 4 \mathrm{H}, J=6.9 \mathrm{~Hz}$ ): Mass $m e 264$ $\left(\mathrm{M}^{-}\right)$.

Di(p-nitrobenzyl) sulfide (If): yellow solid. $1.19 \mathrm{~g} \mathrm{(40 \% ):}$ mp 153.5-156.0 ${ }^{\circ} \mathrm{C}:{ }^{\prime} \mathrm{H}$ NMR $\left(\mathrm{CDCl}_{3}\right) \delta 3.68$ (s. $\left.4 \mathrm{H}\right) .7 .43$ (d. $4 \mathrm{H} . J=8.7 \mathrm{~Hz}$ ). 8.19 (d. $4 \mathrm{H} . J=8.8 \mathrm{~Hz}$ ): Mass $m e 304$ $\left(\mathrm{M}^{-}\right), 168.136$.

Measurement of rate constants for the oxidation reactions of substituted dibenzyl sulfides. A solution of a substituted dibenzyl sulfide $(0.434 \mathrm{mmol})$ and palladium nitrate ( $50 \mathrm{mg} .0 .217 \mathrm{mmol}$ ) in $5 \mathrm{~mL}$ of toluene including 98 $\mathrm{mg}(0.434 \mathrm{mmol})$ of hexadecane as an internal standard was heated to reflux with oxygen gas bubbling slowly through a syringe needle. The amounts of the substituted benzaldehyde generated in the reaction were determined at various time intervals by transferring $0.1 \mathrm{~mL}$ of aliquot into $0.2 \mathrm{~mL}$ of $\mathrm{n}$ hexane in dry ice bath. After the mixture was filtered through Celite the filtrate was analyzed by GC-MS. The semilogaritlumic plot of the amounts of the benzaldehyde against time gave a straight line with a slope of first-order rate constant $k$.

Acknowledgements. Authors thank to Sangnyyung University for the financial support in 2006. 


\section{References}

1. Reid. E. E. Orgunic Chentisty of Bivalent Sulfur: II: Chemical Publishing: New York. U.S.A. 1960.

2. Barnard. D: Bateman. L.: Cumneen. J. I. In Organic Sulfur Compounds. I; Kharasch. N., Ed.; Pergamon Press: New York; U.S.A.. 1961

3. Wallace. T. J: Schriesheim. A. Tetrahedron Lett. 1963. 4. 1131

4. Wallace. T. J.: Schriesheim. A.: Jacobson. N. J. Org. Chem. 1964. 29. 888 .

5. Wallace. T. J.: Pobiner. H.: Baron. F. A.: Schriesheim. A. Chem Ind 1965,945 .

6. Clarkson. S. G.: Basolo. F. Inorg (Chem. 1973. 12, 1528.

7. Ercolani. C: Pennesi, G. Ihorg (Thm Acta 1985, 101, L41

8. O'Shea. S. K.: Wang. W. Wade. R. S.: Castro. C. E. J. Org. Chem. 1996. 61.6388
9. McKillop. A.: Taylor. E. C. Endeavour 1976, 35.88

10. Connelis. A.: Laszlo. P. Swmthe wis 1985. 909

11. Tomi. F.: Li Kam Wah. H.: Postel. M. New J. Chent 1988. 12. 289

12. Li Kam Wah. H.: Postel. M.: Tomi, F. Inorg. Chem 1989, 28. 233.

13. Munyejabo, V: Guillaume, P.: Postel. M. Inorg. Chim Acta 1994. 221.133.

14. Addison. C. C. Coond Chem. Rev 1966. 1.58.

15. Rosenthal. M. R. J. Chem. Ed 1973. 50.331.

16. Jones. C. T.: MeCleverty. I. A.: Rothin. A. S. J. Chent. Soc., Dalton Trans. 1986, 2055.

17. Hwang. S. W. Park, Y. W. J. Ind Eng. Chem 2000. 6, 125

18. Trogler. W. C.: Marzilli. L. G. Inorg. Chem. 1974. 13. 1008.

19. Bhaduri. S. A.: Bratt. I.: Johnson. B. F. G.: Khair. A.: Segal. J. A.: Walters. R.: Zuccaro. C. J. Chent. Soc. Dalton Trans 1981. 234.

20. Still. W. C.: Kaht1. M.: Mitra. A. J. Org. Chem. 1978. 43. 2923. 